\title{
Molecular typing of the red-tide dinoflagellate Gonyaulax polyedra in phytoplankton suspensions
}

\author{
Franco Rollo ${ }^{1,2}$, Stefano Sassaroli ${ }^{1}$, Laurita Boni ${ }^{3}$, Isolina Marota ${ }^{2}$ \\ ${ }^{1}$ Dipartimento di Biologia Molecolare, Cellulare e Animale, Università di Camerino, I-62032 Camerino, Italy \\ ${ }^{2}$ Scuola di Specializzazione in Biochimica e Chimica Clinica, Università di Camerino, I-62032 Camerino, Italy \\ ${ }^{3}$ Dipartimento di Biologia Evoluzionistica e Sperimentale, Università di Bologna, via Imnerio 42, I-40126 Bologna, Italy
}

\begin{abstract}
A group of closely related DNA sequences each approx. 240 base pairs long ('Gp240 family') was detected in the DNA extracted from cultured cells of the red-tide dinoflagellate Gonyaulax polyedra using the polymerase chain reaction. While members of the Gp 240 family appeared to be present in the DNA of all the isolates of $G$. polyedra tested, no related sequence could be detected in the DNA of other dinoflagellates, diatoms or marine bacteria. In a further set of experiments, the PCR system based on the Gp240 DNA was used to probe phytoplankton samples collected in the Northern Adriatic Sea during a red tide caused by G. polyedra. The results showed that the members of the Gp240 family contain a short simple-sequence stretch giving rise to length polymorphism. The potential of this molecular identification system to track $G$. polyedra in its natural environment is discussed. Considerations are also made on the evolution of the simple-sequence loci in marine organisms.
\end{abstract}

KEY WORDS: Gonyaulax polyedra · 'Gp240 family' Simple-sequence loci - Dinoflagellate

\section{INTRODUCTION}

Dinoflagellate protists (Pyrrhophyta) represent a highly diversified phylum, consisting of 2 classes, Dinophyceae, mainly including free-living sea-water organisms, and Syndiniophyceae, intracellular parasites (Dodge 1984). The periodic blooms (red tides) of the Dinophyceae are responsible for a number of ecological and hygienic problems all over the world. For this reason, the dynamics of the red-tide phenomenon and the biology of the causative organisms are the objects of growing interest (Loeblich 1976, Herzog \& Maroteaux 1986, Taylor 1987, Lenaers et al. 1989, 1991). Red tides are a recurrent phenomenon along the coastal waters of the Adriatic Sea and the earliest records of phytoplankton blooms date back to the last century (Forti 1906). The species mostly involved are Prorocentrum micans, Gonyaulax polyedra, Scripsiella trochoidea, Gymnodinium sp., Katodinium rotundatum, and a few others (Boni 1983). Molecular detection and typing methods based on the use of labelled DNA probes or on that of the polymerase chain reaction (PCR) are finding increasing application in tracking wild-type or genetically engineered microorganisms under a variety of environmental situations. These methods can offer significant advantages over traditional methods based on light microscope observations and/or platings (Amici et al. 1991, Britschgi \& Giovannoni 1991). As a first step towards the development of molecular methods to study the red-tide phenomena in the Adriatic Sea, we have set up a PCR system aimed at a repetitive tract 'Gp240 family' of the DNA of the dinoflagellate $G$. polyedra and we have tested it on cultured dinoflagellate cells and on natural phytoplanktonic populations

\section{MATERIALS AND METHODS}

In vitro cultivation of dinoflagellates and diatoms. Clones of the dinoflagellates Cachonina sp., Gonyaulax polyedra Stein, Alexandrium tamarense Lebour, Gymnodinium sp., G. catenatum Graham, G. corii Sch. and of the diatoms Nitzschia closterium W., Sm. and Skeletonema costatum (Grev.) Cl. were isolated from phytoplanktonic associations in coastal (Emilia Rom- 
agna) waters of the Northern Adriatic Sea. The reference cultures of $G$. polyedra were initiated from single spores. All cultures were routinely maintained in $\mathrm{f} / 10$ medium, $25 \%$ salinity at $20^{\circ} \mathrm{C}$ under a $16: 8 \mathrm{~h}$ light:dark regime (ca $1600 \mu \mathrm{W} \mathrm{cm}^{-2}$, from cool white lamps). Antibiotics were added to the medium in the first phases of the cultivation to prevent bacterial growth (Guillard \& Ryther 1963). Prior to harvesting, the cultures were transferred in $\mathrm{f} / 2$ medium and grown to late exponential phase.

DNA extraction and purification. About $300 \mathrm{ml}$ of each culture were sedimented by centrifugation at $2600 \times g$ for $15 \mathrm{~min}$. Cell pellets were mechanically disrupted in the presence of 2 volumes of a mixture containing $50 \mathrm{mM}$ Tris- $\mathrm{HCl} \mathrm{pH} 8.3,50 \mathrm{mM} \mathrm{Na}_{2}$ EDTA, $6 \%(\mathrm{v} / \mathrm{v})$ redistilled phenol and $2 \%(\mathrm{w} / \mathrm{v})$ sodium dodecyl sulphate (SDS). An equal volume of redistilled phenol which had been previously saturated with $50 \mathrm{mM}$ Tris $-\mathrm{HCl} \mathrm{pH} 8.3$ was added to the Iysate and the whole suspension vortexed for $1 \mathrm{~min}$ and centrifuged for 3 min at maximum speed in a top-bench mini-centrifuge. The supernatant was transferred into a new tube, mixed with an equal volume of phenol: chloroform:isoamylic alcohol (24:24:1), vortexed for $30 \mathrm{~s}$ and centrifuged as described above. Eventually the supernatant was washed 3 times with water-saturated ether, brought to $0.2 \mathrm{M}$ (final) with sodium acetate, mixed with $2.5 \mathrm{vol}$ of cold ethanol, and stored overnight at $-20^{\circ} \mathrm{C}$. DNA was precipitated by $10 \mathrm{~min}$ centrifugation in a top-bench mini-centrifuge, desiccated, resuspended in $30 \mu \mathrm{l}$ sterile distilled water, desalted using a 'Gene clean' kit (Bio 101, La Jolla, CA, USA) and stored at $-20^{\circ} \mathrm{C}$ at a concentration of about $100 \mathrm{ng} \mu \mathrm{l}^{-1}$.

The same protocol was used to extract DNA from natural phytoplanktonic populations. In this case, however, the cells were lyophilized a few hours after their recovery. DNA extraction was performed 2 wk later.

Oligonucleotide synthesis. Oligonucleotide primers were prepared using a Beckman 200 A DNA synthesizer. After synthesis, the oligonucleotides were deblocked in $14 \mathrm{M}$ ammonium hydroxide for $17 \mathrm{~h}$ at $55^{\circ} \mathrm{C}$. De-blocked oligonucleotides were purified by elution on a 'DNA grade' G 50 sephadex resin (Pharmacia, Uppsala, Sweden).

Amplification conditions. The PCR was done in a $50 \mu \mathrm{l}$ volume and contained about $100 \mathrm{ng}$ DNA, $50 \mathrm{mM}$ $\mathrm{KCl}, 10 \mathrm{mM}$ Tris- $\mathrm{HCl}$ ( $\mathrm{pH} 8.4$ at room temperature), $1.5 \mathrm{mM} \mathrm{MgCl}_{2}, 100 \mu \mathrm{g} \mathrm{ml}^{-1}$ gelatin, $0.25 \mu \mathrm{M}$ of each oligonucleotide primer, $200 \mu \mathrm{M}$ of each deoxynucleotide triphosphate and 2.5 units of Taq polymerase. The reaction was performed in a DNA 'Thermal Cycler' (Perkin-Elmer, Norwalk, CT, USA). Before adding the polymerase to the reaction mixture, template DNA was denatured at $95^{\circ} \mathrm{C}$ for 7 min. Reaction conditions were as follows: $94^{\circ} \mathrm{C}$ for $20 \mathrm{~s}$ (denaturation), $55^{\circ} \mathrm{C}$ for $20 \mathrm{~s}$ (annealing) and $72^{\circ} \mathrm{C}$ for $30 \mathrm{~s}$ (elongation) for a total of 40 cycles. To avoid DNA carryover, the reaction mixture (oligonucleotides, dNTPS and buffer) was pre-treated with 0.5 U DNase for $45 \mathrm{~min}$ at room temperature. The design of the oligonucleotide primers (see below) is based on a clone of Gonyaulax polyedra DNA in pUC13. The sequence of the insert was determined only in part. This clone was selected from a Sau3AI (partial digest) library of dinoflagellate DNA using a screening strategy aimed at the selection of clones carrying repeated sequences (Rollo et al. 1987, Boni \& Rollo 1992, Sassaroli 1992).

Length polymorphism analysis of PCR amplified DNA. To detect length polymorphisms in the members of the 'Gp240 family', $8 \mu$ of the reaction mixture was loaded on a $2.5 \%$ low-melting agarose minigel containing $0.5 \mu \mathrm{g} \mathrm{ml}^{-1}$ ethidium bromide. After the run the $240 \mathrm{bp}$ amplification band was visualized on a UV transilluminator and the gel cut. The agarose was melted at $70^{\circ} \mathrm{C}$ for $10 \mathrm{~min}$ and $1 \mu \mathrm{l}$ of the agarose/DNA suspension added to a PCR mixture containing $10 \mu \mathrm{Ci}$ of a 32P-dATP in addition to the standard reagents. After 10 amplification cycles sodium acetate $(200 \mathrm{mM}$ final) and cold ethanol $(2.5 \mathrm{vol})$ were added to the reaction mixture and the suspension stored overnight at $-25^{\circ} \mathrm{C}$. The morning after, radioactive DNA was precipitated by centrifugation, and resuspended in $12 \mu \mathrm{l}$ distilled water plus $8 \mu \mathrm{l}$ of a standard formamide-dye mixture. The sample was denatured at $100^{\circ} \mathrm{C}$ for $5 \mathrm{~min}$, then loaded $(4 \mathrm{\mu l})$ on a $50 \times 21 \times 0.025 \mathrm{~cm} 6 \%$ polyacrylamide gel and the gel run for $6 \mathrm{~h}$ at $40 \mathrm{~W}$ constant power. After the run, the gel was oven desiccated and autoradiographed for $3 \mathrm{~d}$.

Molecular cloning and sequence analysis of PCR amplified DNA. A fraction $(8 \mu \mathrm{l})$ of the PCR mixture was directly loaded on a $2.5 \%$ agarose minigel containing $0.5 \mathrm{\mu g} \mathrm{m}^{-1}$ ethidium bromide or the whole reaction volume $(50 \mu \mathrm{l})$ was vacuum concentrated prior to loading After the run the $240 \mathrm{bp}$ amplification band was visualized on a UV transilluminator, the gel cut, and the DNA purified by electroelution followed by ethanol precipitation. Approximately 100 to $300 \mathrm{ng}$ purified DNA was phosphorylated using 3 units of polynucleotide kinase, repaired using 2 units of T4 DNA polymerase and cloned into the Sma I site of the polylinker of pUC18. Sequence analysis of the plasmid inserts was performed using M13 primers and the dideoxy chain termination method adapted to supercoiled plasmid DNA sequencing (Chen \& Seeburg 1985).

Analysis of sequence results. Nucleotide sequences were aligned using the Micro Genie (Beckman, Palo Alto, CA) computer program. Pairwise comparisons were carried out manually. 
Fig. 1. Gel electrophoresis $(2.5 \%$ agarose) of the amplification products (30 PCR cycles) of the DNA (1 ng) isolated from cultured dinoflagellates, diatoms and bacteria using the oligonucleotide primers described in the text Molecular standard, '1 kb ladder', Bethesda Research Laboratories (lane 1), Nitszchia closterium (lane 2), Skeletonema costatum (lane 3). Gymnodinium corii (lane 4), G. catenatum (lane 5), Gymnodinium sp. (lane 6), Cachonina sp. (lane 7), Alexandrium tamarense (lane 8) Gonyaulax polyedra (lane 9) 'bacterioplankton' 1 (lane 10) 'bacterioplankton' 2 (lane 11) negative control, no DNA (lane 12)

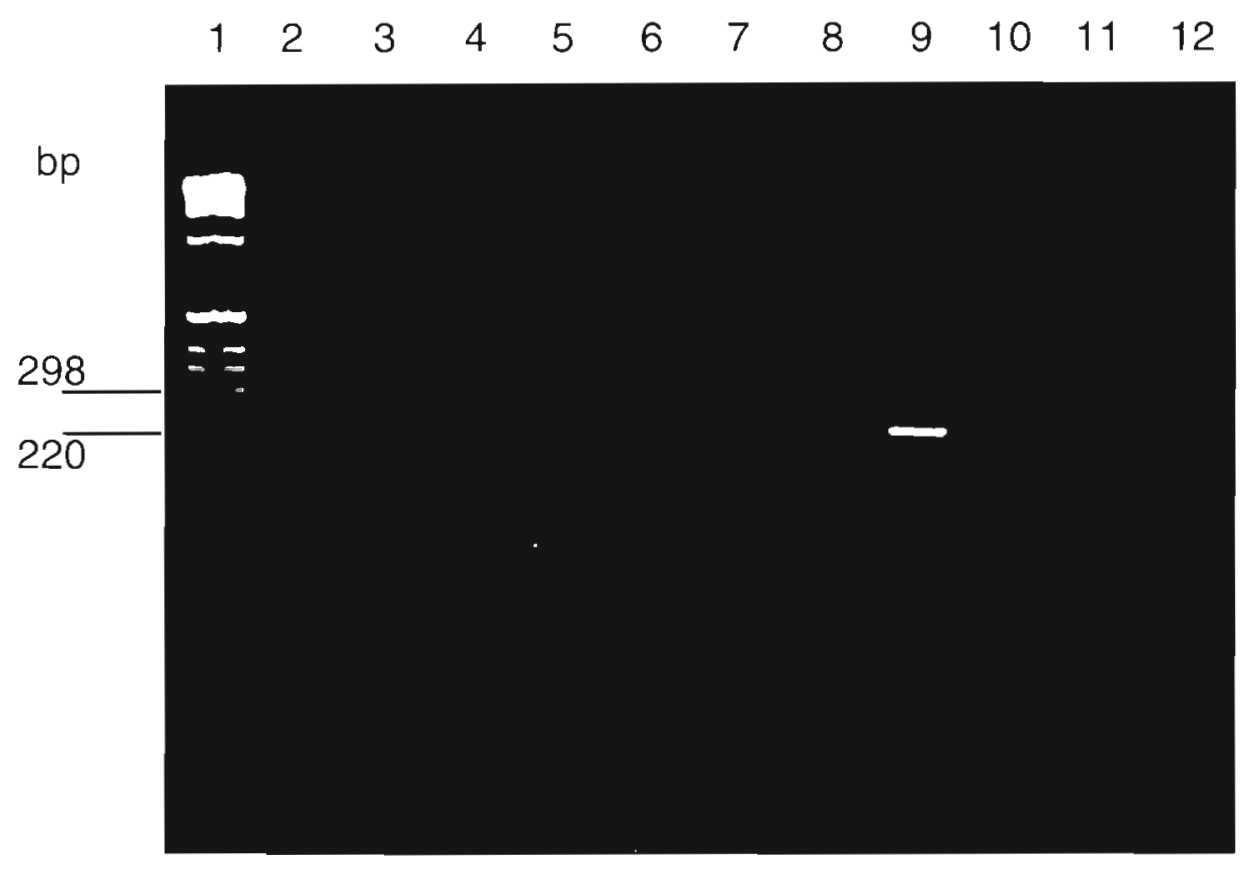

\section{RESULTS}

When the oligonucleotides GAGAGTAAAGGCCTTTGCTGCTTT and TACAAGCGGCCGTGGACGAGGTGG (see 'Material and methods') were tested as PCR primers against the DNA isolated from a clonal in vitro culture (GpII) of the marine dinoflagellate Gonyaulax polyedra a sharp amplification band of about $240 \mathrm{bp}$ in length was produced. On the other hand (Fig. 1), no amplification band, or very weak bands only, could be observed when the same oligonucleotides were used to prime the DNA purified from other cultured dinoflagellates (Alexandrium tamarense, Cachonina sp., Gymnodinium sp., G. catenatum, G. corii), diatoms (Nitszchia closterium, Skeletonema costatum) or marine bacteria ('bacterioplankton' 1 and 2). The successful amplification of the DNA isolated from 3 additional cultures (Gp1, Gp2 and Gp3) of $G$. polyedra, initiated from independent samplings of phytoplankton, using the same couple of primers, showed that the $240 \mathrm{bp}$ tract was a constant component of the dinoflagellate genome (see below). At the same time, the analysis of serial dilutions of $G$. polyedra DNA using the same PCR system showed that a distinct amplification signal was produced by as little as 1 pg DNA (Fig. 2). Further data on the repeated sequence were obtained by cloning the amplified DNA into a plasmid vector and by sequencing the inserts of individual PCR clones. Results (Fig. 3) referring to 18 PCR clones from $4 \mathrm{G}$. polyedra cultures showed that, actually, the $240 \mathrm{bp}$ band was made up by a range of different, though closely related, sequences (hence the name 'Gp240 family').
The potential of the 'Gp240 family' as a possible target for a molecular detection system for Gonyaulax polyedra was then tested using whole phytoplankton samples.

In July 1990 an intense Gonyaulax polyedra red tide occurred in the coastal waters of Emilia Romagna (Northern Adriatic Sea). Phytoplankton samples were

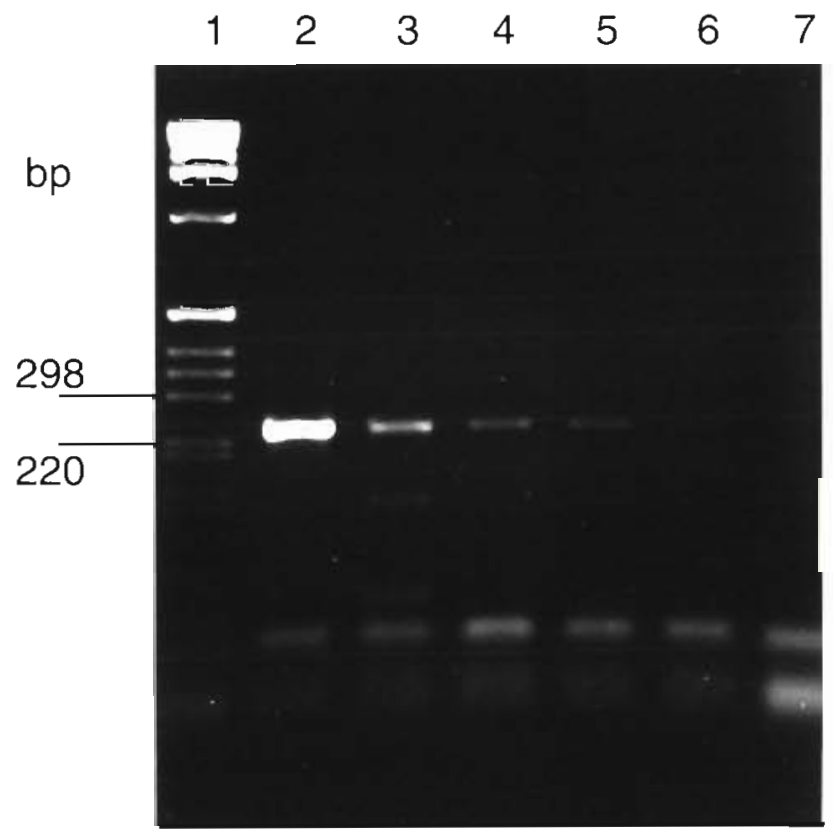

Fig. 2. PCR amplification of serial dilutions of Gonyaulax

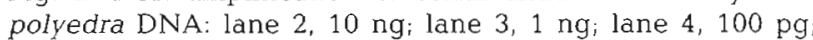
lane 5, $10 \mathrm{pg}$; lane 6, $1 \mathrm{pg}$; lane 7, negative control. Molecular standard (as in Fig. 1) in lane 1 


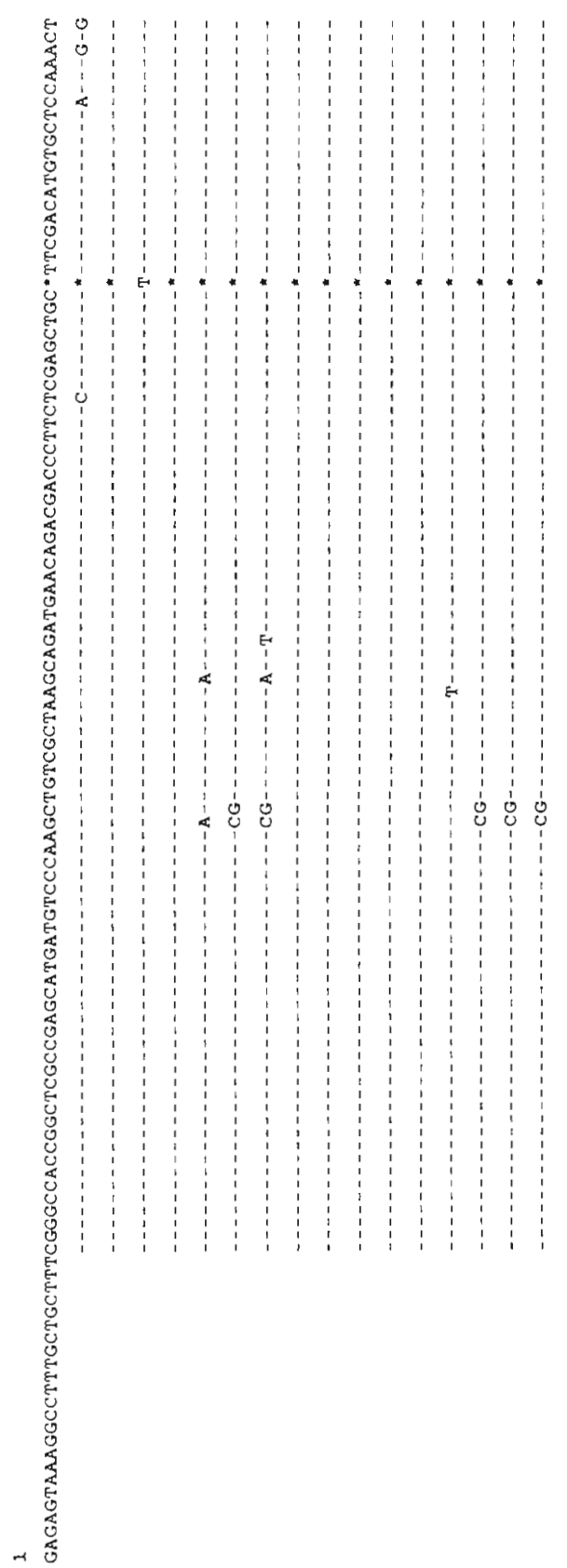

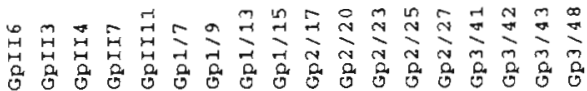

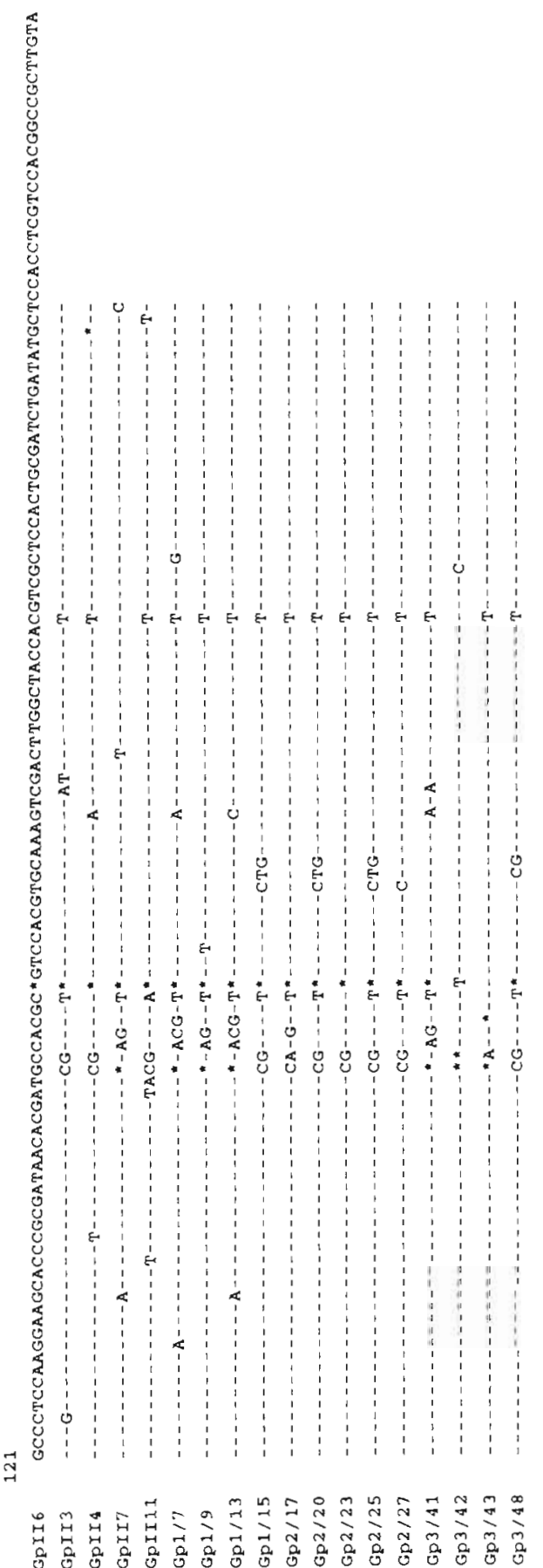

Fig. 3. Nucleotide sequences of 18 members of the 'Gp240 family' from 4 different clonal cultures of Gonyaulax polyedra (GpII Gp1, Gp2 and Gp3). All sequences were aligned with respect to the GpII-6 sequence. Dashes denote identities, stars denote insertions/deletions. The amplification primers are shown at both sides of the reference sequence and are not included in the alignments. In principle, as the sequences were determined on the basis of individual clones of $\mathrm{PCR}$ amplified DNA they can be affected by errors stemming from polymerase misincorporations. However we found that under the conditions employed misincorporations accounted for only $<0.1 \%$ of the nucleotide substitutions (error rate per nucleotide per PCR cycle: $\mathrm{p}=1 / 27000$ according to Eckert \& Kunkel 1991) collected over a stretch of sea about $90 \mathrm{~km}$ in length encompassing the area affected by the red-tide phenomenon.

DNA was isolated from 4 phytoplanktonic suspensions (Table 1) as reported in 'Materials and methods' and submitted to 40 PCR cycles using the couple of oligonucleotide primers specific for the Gp240 family. The reaction products were thoroughly characterized for length and sequence polymorphism as described below.

As a first step, amplified DNA was fractionated by electrophoresis on $2.5 \%$ low-melting agarose and reamplified using a reaction medium containing $\alpha 32 \mathrm{P}$ $\mathrm{dATP}$ in addition to the standard reagents. Once made radioactive, the DNA fragments were fractionated on a high resolution polyacrylamide gel and their size was 


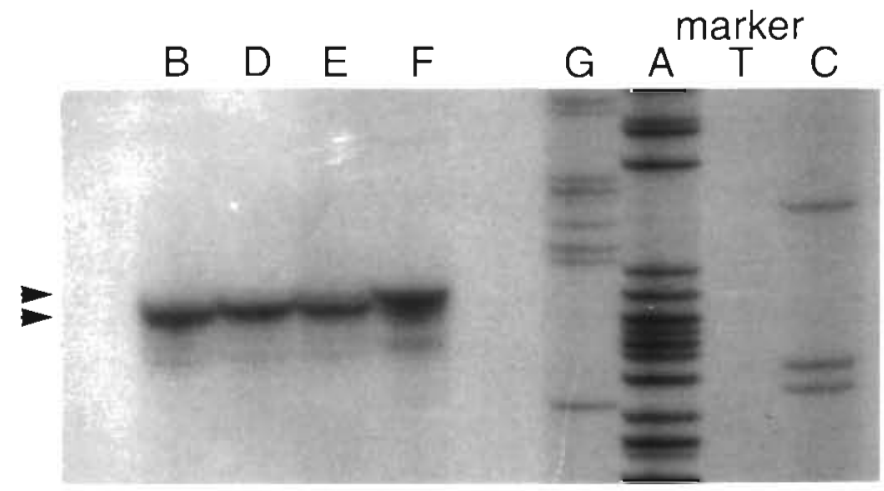

Fig. 4. Test for polymorphism of the Gp240 sequences from different sampling sites (see Table 1) in the Northern Adriatic Sea The sequencing reaction at the side serves as size marker. The arrowheads indicate the length polymorphism.

accurately determined using a sequencing reaction as size standard. As one can observe (Fig. 4) samples B, D and $E$ show a major band (arrowhead) and several fainter bands, while the major band shown by sample $F$ is 1 nucleotide longer than the others (arrowhead).

To determine the precise nature of the length polymorphism, amplified fragments from samples D and $F$ were cloned into a plasmid vector and the nucleotide sequence of the inserts of 8 recombinant clones was determined. The alignment of the $8 \mathrm{Gp} 240$ sequences (Fig. 5) shows that their central portion is occupied by a simple-sequence stretch based on the repetition of the trinucleotide GCT (overlined). The motif becomes evident if one observes the GpF03 variant, in which the trinucleotide GCT is repeated 3 times instead of 2 .

\section{DISCUSSION AND CONCLUSIONS}

The present results demonstrate that the Gp240 DNA can be used as a specific marker for the Gonyaulax polyedra species. Our results also show that as little as $1 \mathrm{pg}$ of total dinoflagellate DNA can be

Table 1 Gonyaulax polyedra. Phytoplankton samples collected in the coastal waters of Emilia Romagna (Northern Adriatic Sea) during the July 1990 red tide, and used in the present study

\begin{tabular}{|clc|}
\hline Sample & Source & G. polyedra cells ${ }^{-1}$ a \\
\hline B & Cesenatico & $1.5 \times 10^{6}$ \\
D & Marina di Ravenna & $1.0 \times 10^{5}$ \\
E & Goro & $5.0 \times 10^{5}$ \\
F & Milano marittima & $5.0 \times 10^{4}$ \\
& \\
&
\end{tabular}

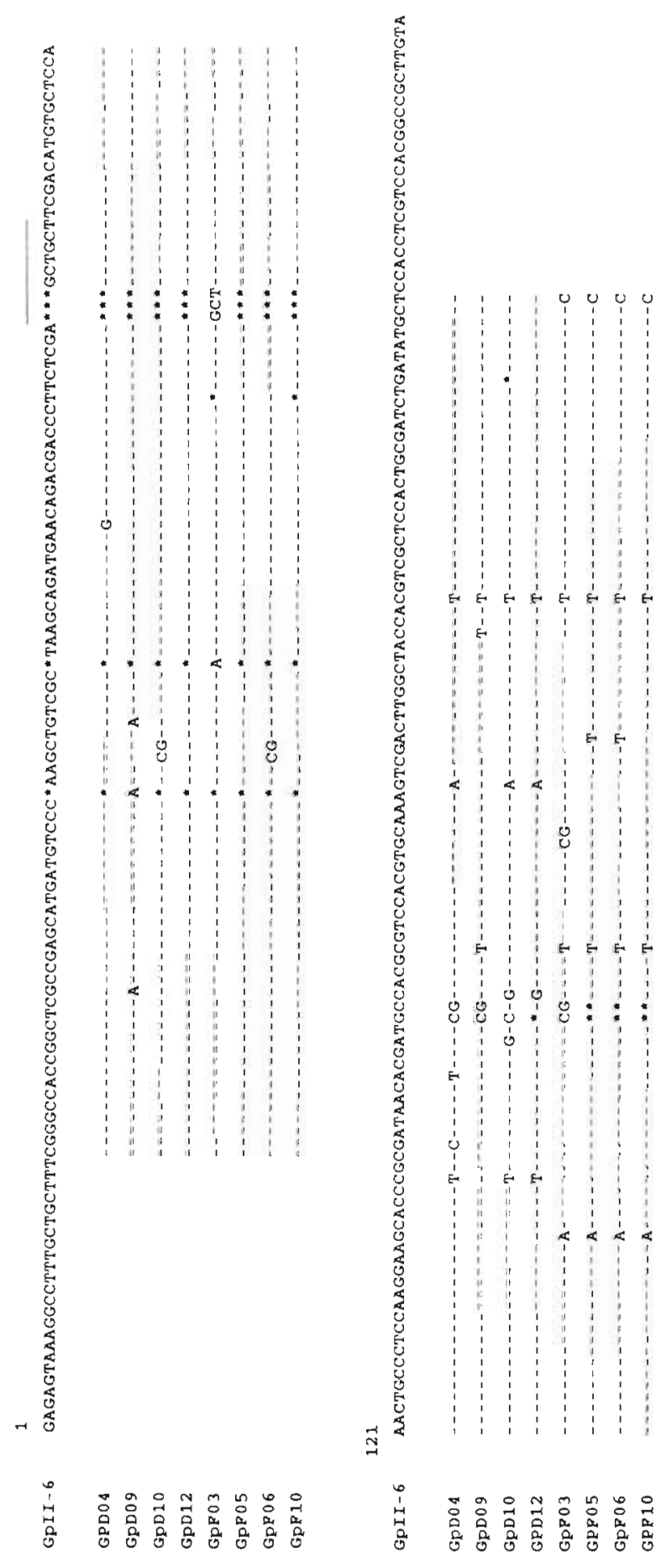

Fig. 5. Alignment of the Gp240 sequences obtained from sampling sites $D$ and $F$ with a reference sequence (GpII-6). Dashes denote identities, stars denote insertions/deletions. The amplification primers are shown at both sides of the sequences and are not included in the alignments. Simplesequence stretches are overlined 
detected using PCR. The sensitivity of this approach can be fully appreciated if one considers that a single cell of $G$. polyedra contains about $200 \mathrm{pg}$ of DNA (Rizzo 1987). The fact that we are able to obtain a distinct amplification signal starting from 1 pg DNA indicates that the Gp240 sequences are high copy number (at least 200 copies/dinoflagellate nucleus). Due to its specificity and sensitivity, several interesting applications can be envisaged for our molecular detection system.

As shown in the present study, we can already use PCR to detect Gonyaulax polyedra cells in whole suspensions of phytoplankton. In principle, the detection test could be made faster by the use of a rapid DNA extraction method such as the 'microwave miniprep' method of Goodwin \& Lee (1993) instead of that based on grinding of the cells by mortar and pestle used in this research. In addition, the test could be made quantitative by monitoring the accumulation of ethidium bromide fluorescence during the amplification process as proposed by Higuchi et al. (1993). Other possible applications of our test could include the detection of benthic dinoflagellate cysts (Anderson \& Wall 1978), the study of the predation of dinoflagellates by microzooplankton (Cattani \& Corni 1992) and the elucidation of the dynamics of extracellular DNA in the marine environment (Paul et al. 1987).

The present analysis of the phytoplankton from different zones of the Adriatic Sea demonstrates that the members of the Gp240 family contain a short simplesequence stretch based on the repetition of a trinucleotide, which can give rise to length polymorphisms.

As described by Tautz (1989) and by Schlötterer et al. (1991) simple-sequence stretches occur as interspersed repetitive elements in eukaryotic genomes. They are thought to arise by slippage events, and tend to be hypervariable in length.

The finding of a simple-sequence stretch giving rise to sequence polymorphism in Gp240 DNA strongly suggests that this is non-coding DNA (Tautz 1989).

It may also be of interest to make a few considerations about the origin and evolution of the Gp240 family. The earliest palaeontological record of Gonyaulax polyedra in a marine ecosystem (Wall \& Dale 1968) is represented by remnants of cysts ('lingulodinioid cysts') which have been found in approximately 25 million year (Myr) old Upper Miocene sediments. This time span can be seen in relation to the divergence of the $18 \mathrm{Gp} 240$ sequences of Fig. 3, which show an average sequence divergence, due to base substitutions, of $4.6 \pm 1.934 \%$. If we now assume that the Gp240 family is as old as the dinoflagellate itself - just a circumstantial hypothesis at the moment - we find that the members of the Gp240 family have diverged at a rate of about $0.18 \% \mathrm{Myr}^{-1}$. Quite interestingly, such a fig- ure would fall very close to that reported for simplesequence loci in marine organisms $\left(0.15 \% \mathrm{Myr}^{-1}\right)$ by Schlötterer et al. (1991).

Acknowledgements. The authors gratefully acknowledge the financial support of the Ministero per l'Università e la Ricerca Scientifica e Tecnologica (M.U.R.S.T.). Uncharacterized suspensions of marine bacteria ('bacterioplankton' 1 and 2) were a gift of G. Paolo Legnani, Istituto di Igiene, Università di Bologna.

\section{LITERATURE CITED}

Amici O, Bazzicalupo M, Gallori E, Rollo F (1991) Monitoring a genetically engineered bacterium in a freshwater environment by rapid enzymatic amplification of a synthetic DNA 'number plate' Appl Microbiol Biotechnol 36: $222-227$

Anderson DM, Wall D (1978) The potential of benthic cysts of Gonyaulax tamarensis and Gonyaulax excavata in initiating toxic dinoflagellate blooms. J Phycol 14:224-234

Boni L (1983) Red tides off the coast of Emilia Romagna (North-Western Adriatic Sea) from 1975 to 1982. Inf Bot Ital 15:18-24

Boni L, Rollo F (1992) Molecular detection and characterization of marine dinoflagellates and their symbionts: potentials and pitfalls. Sci total Environ (Suppl) 945-955

Britschgi TB, Giovannoni SJ (1991) Phylogenetic analysis of a natural marine bacterioplankton population by rRNA gene cloning and sequencing. Appl environ Microbiol 57: $1707-1713$

Cattani O. Corni MG (1992) The role of zooplankton in eutrophication, with special reference to the Northern Adriatic Sea. Sci total Environ (Suppl) 137-158

Chen EJ, Seeburg PH (1985) Supercoil sequencing: a fast simple method for sequencing plasmid DNA. DNA 4:165-170

Dodge JD (1984) Dinoflagellate taxonomy. In: Spector DL (ed) Dinoflagellates. Academic Press, New York, p 17-42

Eckert KA, Kunkel TA (1991) DNA polymerase fidelity and the polymerase chain reaction. PCR Methods Applic 1: $17-24$

Forti A (1906) Alcune osservazioni sul 'mare sporco' ed in particolare sul fenomeno arvenuto nel 1905. Nuovo G Botan Ital NS 13(4):81-132

Goodwin DC, Lee SB (1993) Microwave miniprep of total genomic DNA from fungi, plants, protists and animals for PCR. BioTechniques 15:438-444

Guillard R, Ryther J (1963) Studies on marine planktonic diatoms. I. Cyclotella nana Husted and Detonula confervacea Cleve. Can J Microbiol 8:229-239

Herzog M. Maroteaux L (1986) Dinoflagellate 17S rRNA sequence inferred from the gene sequence: evolutionary implications. Proc natl Acad Sci USA 83:8644-8648

Higuchi R, Fockler C, Dollinger G, Watson R (1993) Kinetic PCR analysis: real-time monitoring of DNA amplification reactions. Bio/Technology 11:1026-1030

Lenaers G, Maroteaux L, Michot B, Herzog M (1989) Dinoflagellates in evolution. A molecular phylogenetic analysis of large subunit ribosomal RNA. J molec Evol 29:40-51

Lenaers G, Scholin C, Bhaud Y, Saint-Hilaire D, Herzog M (1991) A molecular phylogeny of dinoflagellate protists (Pyrrhophyta) inferred from the sequence of $24 \mathrm{~S}$ rRNA. divergent domains D1 and D8. J molec Evol 32:53-63

Loeblich AR (1976) Dinoflagellate evolution: speculation and evidence. J Protozool 23:13-28 
Margalef R (1974) Phytoplankton counting. In: Vollenweider RA (ed) A manual on methods for measuring primary production in aquatic environments. IBP handbook 12. Blackwell Scientific Publications, p 7-14

Paul JH, Jeffrey WD, DeFlaun MF (1987) Dynamic of extracellular DNA in the marine environment. Appl environ Microbiol 53:170-179

Rizzo PJ (1987) Biochemistry of the dinoflagellate nucleus. Bot Monogr 21:143-173

Rollo F, Amici A, Foresi F, Di Silvestro I (1987) Construction and characterization of a cloned probe for the detection of Phoma tracheiphila in plant tissues. Appl Microbiol Biotechnol 26:352-357
Sassaroli S (1992) Monitoraggio molecolare di Gonyaulax polyedra. Tesi di Laurea, University of Camerino

Schlötterer C, Amos B, Tautz D (1991) Conservation of polymorphic simple sequence loci in cetacean species. Nature $354: 63-65$

Tautz D (1989) Hypervariability of simple sequences as a general source for polymorphic DNA markers. Nucleic Acids Res 17:6463-6471

Taylor FJR (1987) The biology of dinoflagellates. Bot Monogr 21

Wall D, Dale B (1968) Modern dinoflagellate cysts and the evolution of the Peridiniales. Micropaleontology 14: $265-304$ 